Environment Conservation Journal 15(1\&2) 207-211, 2014

ISSN 0972-3099 (Print) 2278-5124 (Online)

Abstracted and Indexed

\title{
Studies on the fecundity of Mastacembelus armatus fish from River Narmada in West Nimar (M.P.)
}

\author{
Sunita Bakawale $\bowtie$ and R. R. Kanhere
}

\section{Received: 15.06.2013}

\author{
Revised: 24.09.2013
}

Accepted: 10.10.2013

\begin{abstract}
The spiny eel Mastacembelus armatus is an economically important freshwater food fish native of India, Pakistan, Sri Lanka, Thailand, Indonesia and other parts of South-east Asia. The study was conducted from river Narmada to determine the fecundity of Mastacembelus armatus during the period of one year (2006-2007). Fecundity of fish was determined by numerical method. It ranged from 1872 eggs to 5402 eggs in total length range of 42.1 to $47.9 \mathrm{cms}$. The Fecundity of Mastacembelus armatus in relation to fish length, fish weight \& ovary weight was worked out.
\end{abstract}

Keywords: Fecundity, Mastacembelus armatus, Narmada River, West Nimar

\section{Introduction}

Fecundity is defined as a season's crop or the number of eggs released by an individual fish during a spawning season. The number of eggs shed by different species may vary considerably. Even individuals of the same species produce varying number of eggs, depending of their age, length, weight, gonad length, gonad weight, environmental conditions, etc. The reproductive potential, i.e., fecundity is an important biological parameter that plays a significant role in evaluating the commercial potentials of fish stocks (GómezMárquez 2003). Many workers have worked on the fecundity of different fish, Simpson (1951), Begenal (1957), Qasim \& Qayyum (1963), Karim and Hossain (1972), Saxena et al. (1979), Sikder and Das (1980), Serajuddin, and Mustafa (1994), Sikarwar (1994), Narejo et al. (2003). The present study was undertaken to study the fecundity in Mastacembelus armatus fish captured and sold in local markets in west nimar (M.P.).

\section{Material and methods}

The specimens were brought to the laboratory, their total lengths, total weights and ovary weights were recorded, and then the ovaries were preserved in 10 $\%$ formalin. After about 15 days the ovaries

Author's Address

1 Deptt. Of Zoology, Govt. P.G. College Mandsaur (M.P.)

${ }^{2}$ Govt. Girls College Barwani (M.P.)

E-mail: sunnu60@yahoo.com become hard,ovarian tissue were removed from the eggs, and formalin changed. By frequently teasing the ovaries apart and shaking the storage jars, the eggs were completely separated from, the surrounding ovarian tissue and were ready for counting. Only mature yolky eggs were counted from, each ovary. For fecundity study a small sample of 1.0 gram was taken, ova teased out of the follicles and counts were made of all ova, comprising of mature group. The fecundity was estimated by multiplying the ova count per gram of ovary by the total weight of the ovary. The absolute fecundity was calculated by using the following formula Bagenel (1967)_and adopting the method described by Baxter (1959), a random sample from a given batch of eggs was weighed and eggs in the sample counted. The number obtained was raised by the ratio:

Total weight of ovary/ weight of sample, to find the total number of eggs (Fecundity).

$$
\begin{gathered}
\boldsymbol{F}=\frac{\boldsymbol{W}}{\boldsymbol{W} \mathbf{1}+\boldsymbol{W} \mathbf{2}+\boldsymbol{W} \mathbf{3}} \\
\mathrm{X}(\mathrm{N} 1+\mathrm{N} 2+\mathrm{N} 3)
\end{gathered}
$$

Where,

$\mathrm{F}=$ Fecundity $\mathrm{W}=$ Weight of ovary, $\mathrm{W} 1=$ Weight of sub sample (a),W2= Weight of sub sample (b), W3 = Weight of sub sample (c), N1= Ova counts of sub sample (a), N2= Ova counts of sub sample (b), $\mathrm{N} 3=$ Ova counts of sub sample (c). 
The trends of relationship between fecundity and total length, fecundity and total weight of fish, Fecundity and ovary weight were examined by using the least squares method i.e. $Y=a+b x, Y=$ Fecundity, $\mathrm{X}=$ various body measurements, $\left(\mathrm{T}_{1}=\right.$ total length, $\mathrm{TW}=$ total weight of fish, and $\mathrm{Ow}=$ ovary weight), $\mathrm{a} \quad \& \quad \mathrm{~b}=$ constant.Correlation coefficient of these relationships was computed. A part from absolute fecundity, the comparative fecundity was also calculated Das (1964). By dividing total number of eggs by total weight of the fish.

$$
\text { C.F. }=\frac{\text { Total No.of Ova }}{\text { Total Weight of Fish }}
$$

\section{Results and Discussion}

The fecundity of 5 mature females ranging from 42.1 to $47.9 \mathrm{cms}$. in total length was estimated, the data are represented in (Table no.1 \& 2). The average fecundity ranged from 1872 to 5402 , the number of ova per gram weight of ovary 148 to234 and number of ova per gram weight fish from 9.88 to 18.53 .

\section{Fecundity \& ovary weight}

The relationship between ovary weight and fecundity has been shown in (Fig-4).

The equation derived is:

$$
Y=619.325+128.6709 X(r=0.9921) \text {. }
$$

The value of correlation coefficient ( $r$ ) was found to be 0.9921 , which indicates a high degree of positive correlation between the parameters.
Least square regression was carried out on both the observed values for fecundity and fish weight. It show a high degree of correlation $(r=0.9799)$ regression between fecundity and body weight as follows: $Y=-4686.0906+34.2869 X$.

Fecundity \& total length of fish

As the relationship between fecundity and total length of fish was expected to be exponential,

a least square regression and show a positive correlation $(r=0.7596)$.

\section{$Y=-14945.5355+396.8491 X$}

\section{Comprative fecundity}

Comparative fecundity varied 9.88 to 18.53 in total length range from 42.1 to $47.9 \mathrm{cms}$ shown in (table no.1). The relationship \& total length, total weight and ovary weight have been represented by diagrams Fig. no.- 1, 2, 3 \& 4.

\section{Body weight \& body length relationship}

Least square regression was carried out on both observed values for body weight and length of fish. It shows a high degree of positive correlation $(r=$ 0.7809) regression equation between body weight and body length of fish is as follows:

$$
Y=218.8086+0.0523 X
$$

During the present study of Mastacembelus armatus, the fecundity varies from 1872 to 5402 in weight range of 189.4 to 291.5 grams. The value of C.F. was found from 9.88 to 18.53 .

Table1: Fecundity and body weight of fishes

\begin{tabular}{|l|l|l|l|l|l|l|}
\hline No. & $\begin{array}{l}\text { Total Length } \\
\text { of Fish } \\
(\text { Cms. })\end{array}$ & $\begin{array}{l}\text { Total } \\
\text { Weight of } \\
\text { Fish } \\
(\text { Gram) }\end{array}$ & $\begin{array}{l}\text { Ovary } \\
\text { Weight } \\
\text { (Gram) }\end{array}$ & $\begin{array}{l}\text { No. of } \\
\text { OVA/Gm. } \\
\text { wt. of ovary }\end{array}$ & $\begin{array}{l}\text { Total } \\
\text { No. of } \\
\text { OVA } \\
(\text { F.) }\end{array}$ & $\begin{array}{l}\text { No. of } \\
\text { OVA./gm.wt. } \\
\text { fish (C.F. })\end{array}$ \\
\hline 1 & 42.1 & 189.4 & 8 & 148 & 1872 & 9.88 \\
\hline 2 & 42.5 & 193.1 & 11.8 & 155 & 2018 & 10.45 \\
\hline 3 & 44.6 & 199.0 & 14.2 & 157 & 2210 & 11.10 \\
\hline 4 & 47.7 & 216.4 & 18 & 185 & 2826 & 13.06 \\
\hline 5 & 47.9 & 291.5 & 36.5 & 234 & 5402 & 18.53 \\
\hline$*$ F= Fecundity,
\end{tabular}


Narejo (2003) calculated the fecundity of M. cuchia ranging 260-5890 and $M$. armatus ranging 58010980 respectively. Karim \& Hossain (1972) also reported the occurrence of low absolute fecundity (2013 eggs on an average) in a closely related species, Mastacembelus pancalus. Kabir et al. (1998) in Gadusia chapra, also reported the fecundity increased with the increasing length and weight of the fish. Das (1964) used comparative fecundity for evaluating the actual breeding powers of fishes and considered Mystus bleekeri with an average of 15962 to be a "Prolific breeder" value of C.F. being 7.03.The fecundity of Tor tor varied from 9600 to 41250 in weighing range of 250 gram to 2200 grams Sikarwar (1994). The above observations on the fecundity and its relationship with length and weight of the fish and weight of ovary are suitable factors for estimating the fecundity of Mastacembelus armatus. In the present study, it was found that fish spawns once in a year with single spawning peak. Fecundity was found to be low in M. armatus due to large size of eggs.

Table no. - 2: Regression Equations, Data and Analysis of Variance for Linearty of various Relationships in Mastacembelus armatus

\begin{tabular}{|l|l|l|l|}
\hline S.No. & $\begin{array}{l}\text { Relationship } \\
\text { between Fecundity, } \\
\text { length and weight }\end{array}$ & $\begin{array}{l}\text { Correlation } \\
\text { Coefficient }(\mathbf{r})\end{array}$ & $\begin{array}{l}\text { Regression Equations of Fecundity and } \\
\text { various Factor }(\mathbf{Y = a}+\mathbf{b} \text { X) }\end{array}$ \\
\hline 1 & Total fish length (L) & 0.7597519 & $\mathrm{Y}=-14945.5355+396.8491 \mathrm{X}$ \\
\hline 2 & Total fish weight $(\mathrm{W})$ & 0.979897 & $\mathrm{Y}=-4686.0908+34.2869 \mathrm{X}$ \\
\hline 3 & Ovary weight $(\mathrm{w})$ & 0.992066525 & $\mathrm{Y}=618.864243+128.6969354 \mathrm{X}$ \\
\hline \multicolumn{3}{|l|}{ Relationship between length and weight } \\
\hline 4 & $\begin{array}{l}\text { Total fish weight \& } \\
\text { total fish length }\end{array}$ & 0.780903565 & $\mathrm{Y}=218.8086+0.0523 \mathrm{X}$ \\
\hline
\end{tabular}

Fig.1 : Relationship between body length \& comparative fecundity of Mastacembelus armatus

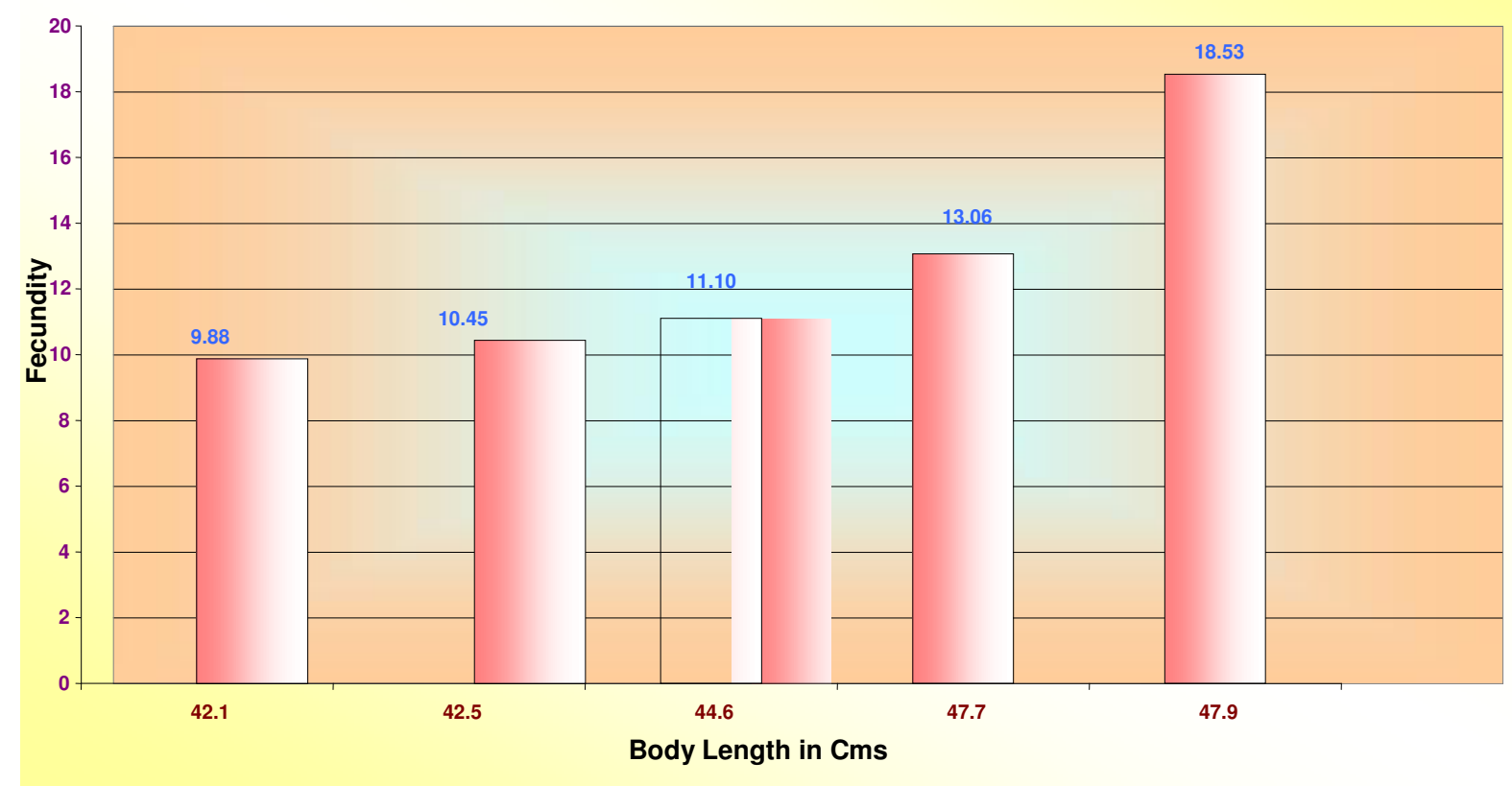


Fig. 2 : Relationship between fecundity \& body weight of Mastacembelus armatus

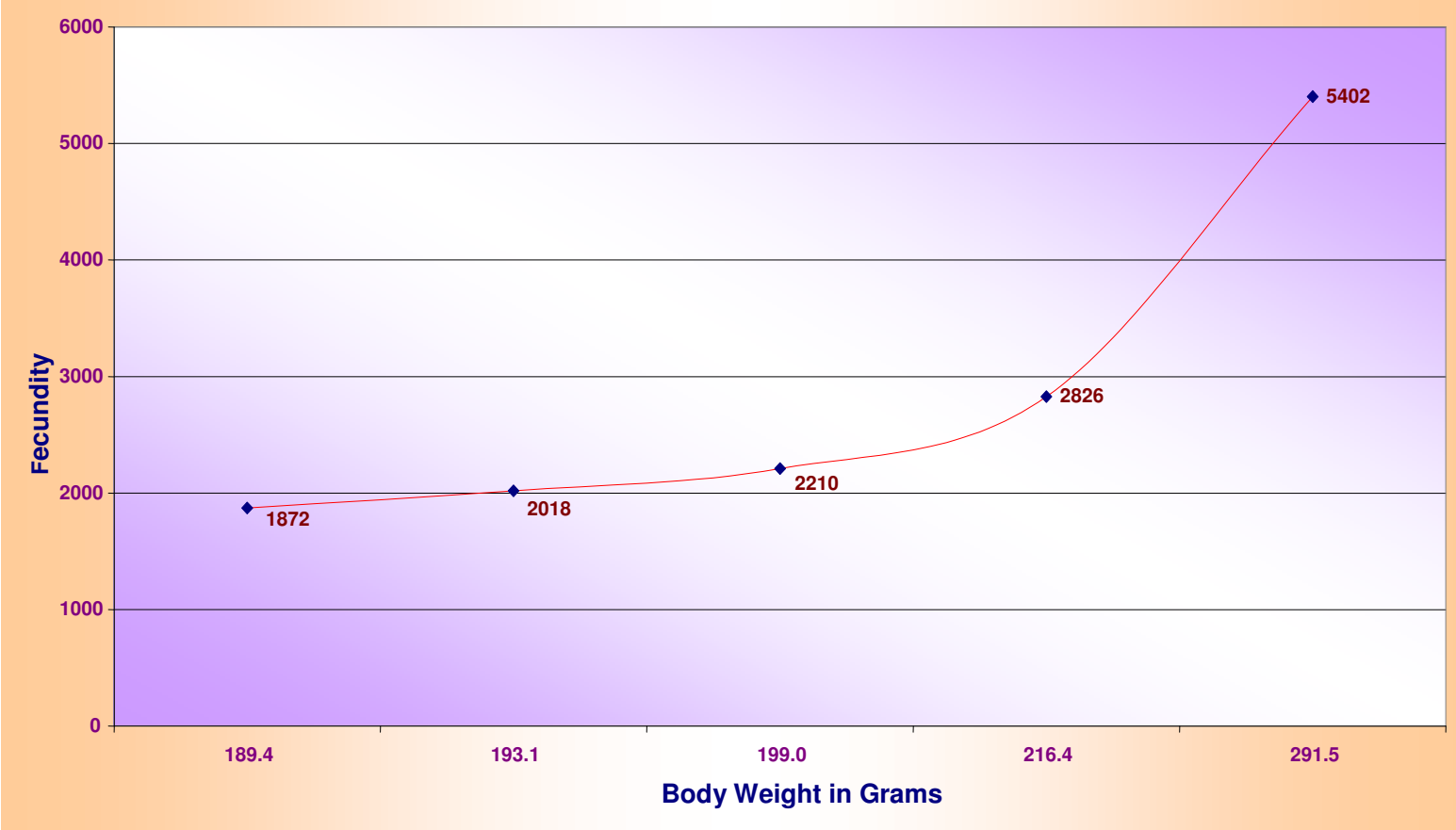

Fig. 3 : Relationship between Fecundity \& Body Length of Mastacembelus armatus

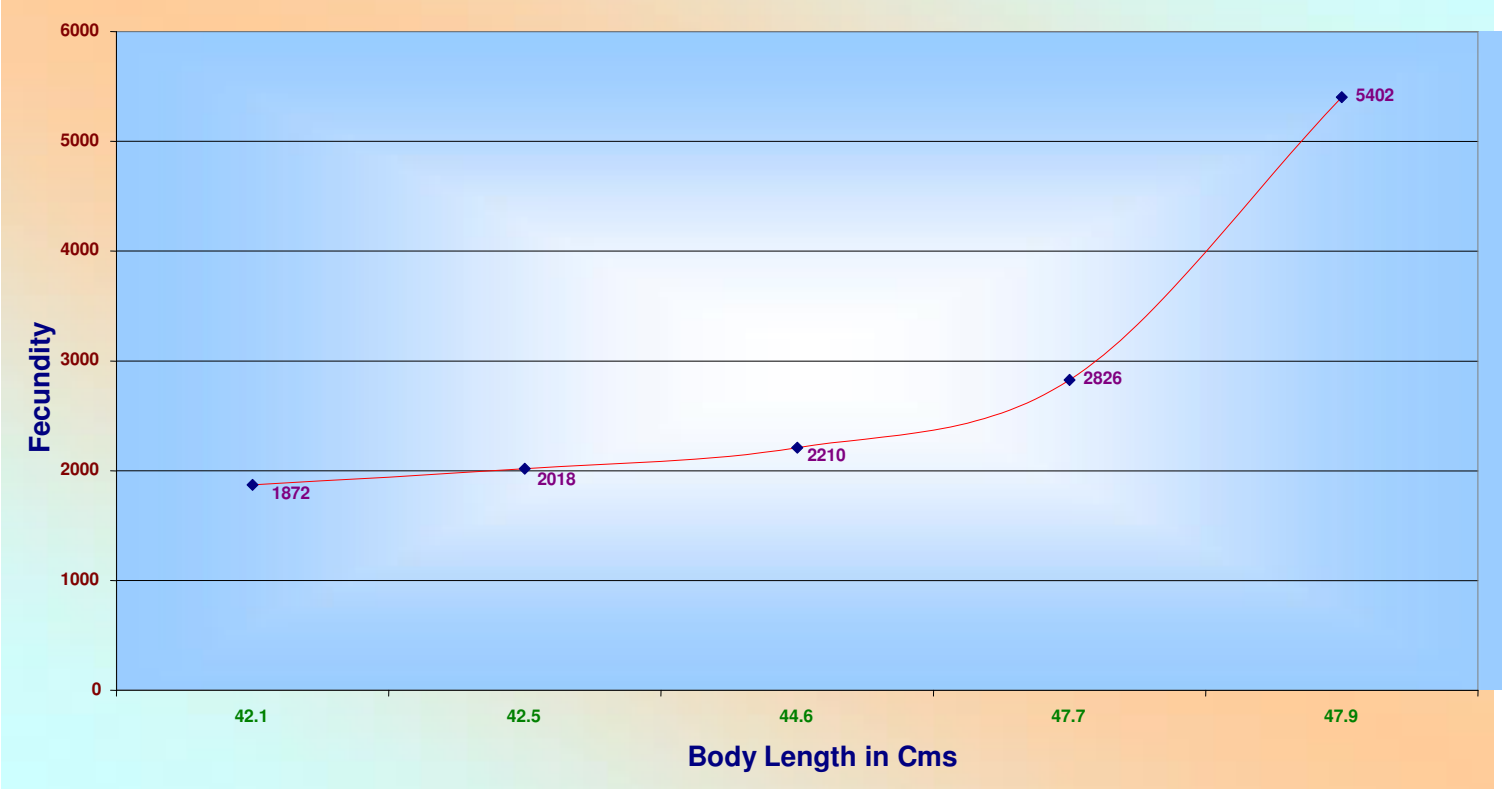


Fig. 4 : Relationship between Fecundity \& Ovary Weight of Mastacembelus armatus

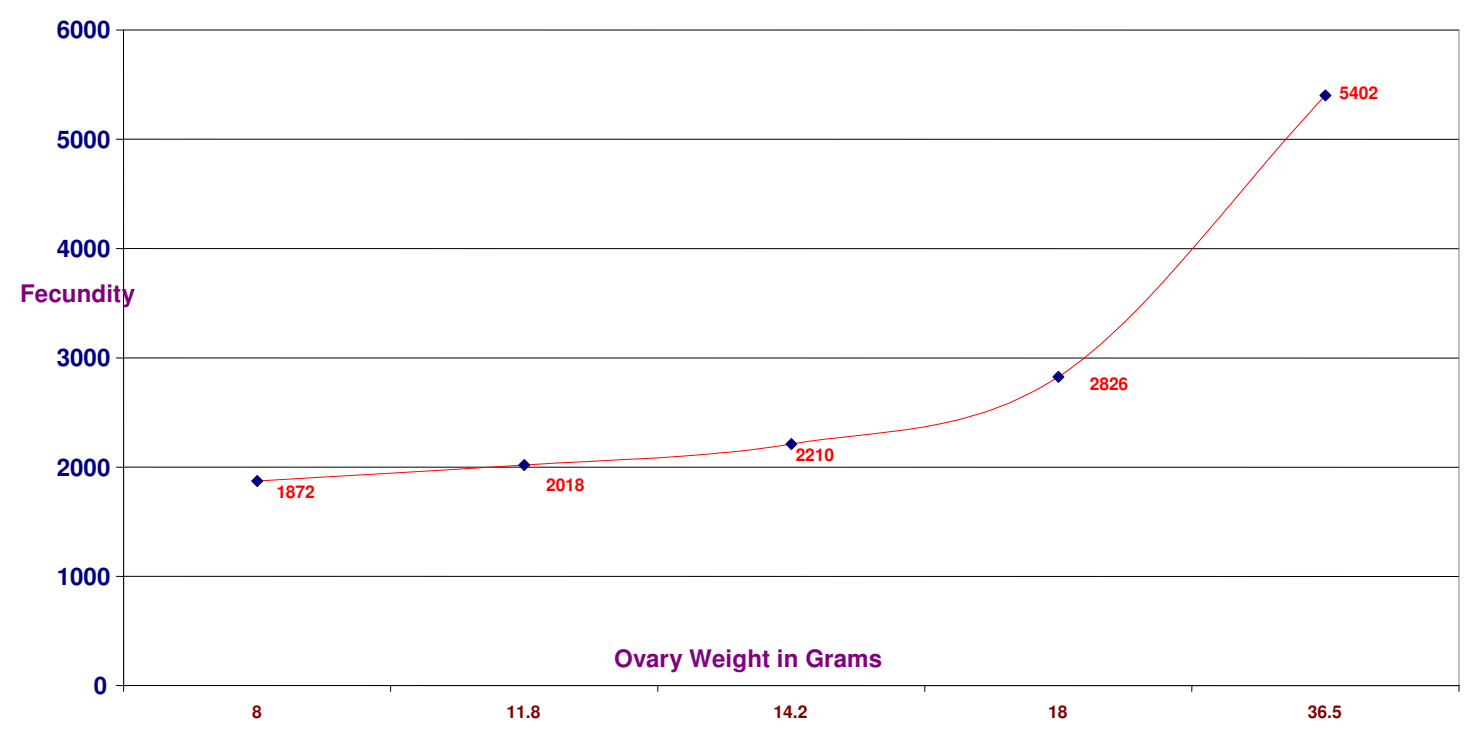

\section{References}

Bagenal, T.B. 1957. Annual variations in fish fecundity. Journal of Marine Biological Association United Kingdom 36: 377-382.

Bagenal, T. B. 1967. A Short view of fish fecundity in biological basis of freshwater fish production E.D.S.D. Gerking Oxford 89-111pp.

Baxter, I. G. 1959 Fecundities of Winter spring and summer, Autmn herring spawnrs Extrait du Journal du Conseil. International Pour 1. Exploration delamer- 25:1.

Das S. M. 1964. A Study on the fecundity of some fresh water fishes of India with note on new aspect of comparative fecundity Ichthyologica 3: 33-36pp.

Gomez-Marquez, J.L., Pena-Mendoza, B., Salgado-Ugarte, I.H. \& Guzmán-Arroyo, M. 2003. Reproductive aspects of Oreochromis niloticus (Perciformes: Cichlidae) at Coatetelco lake, Morelos, Mexico. Revista de Biologia Tropical 51(1): 221-228.

Kabir, A.K.M.A., M.A. Hossain, S.M. Rahmatullah, S. Dewan and M.S. Islam 1998. Studies on the gonadoso-matic index and fecundity of chapila (Gudusia chapra Ham.). Bangladesh Journal of Fisheries Research 2 (2): 195200.

Karim, M.A., and Hossain, A. 1972 Studies on the biology of Mastacembelus pancalus (spiny eel, Hamilton) in artificial ponds. Part II, sexual maturity and fecundity.Bangladesh J. Biol. Agric. Sci., 1(2), pp. 15-18.

Narejo, N.T., Rahmatullah, S.M., and Rashid, M.M. 2002 Studies on the reproductive biology of freshwater spiny eel,
Mastacembalus armatus (Lacepede) reared in the cemented cisterns of BAU, Mymensingh, Bangladesh. Pakistan Journal of Biological Sciences, 5(7), pp. 809-811.

Narejo, N.T. 2003. Comparative studies on the biology and culture of Monopterus cuchia and Mastacembelus armatus of Mymensingh region. Ph. D. Thesis, Department of Aquaculture, Bangladesh Agricultural University, Mymensingh, Bangladesh. 205 pp.

Qasim, S.Z. and Qayyum, A. 1963. Fecundities of some freshwater fish. Proceedings of the National Institute of Sciences of India 29: 373-382.

Saxena, O.P., Bhatia, H.K., and Chowdhery, V. 1979 Cytological study of oocytes of the fish, Mastacembelus armatus with particular reference to the localization of protein and nucleic acids. Matsya, 5, pp. 1-10.

Serajuddin, M., and Mustafa, S. (1994) Feeding specialization in adult spiny eel, Mastacembelus armatus. Asian Fish. Sci., 7, pp. 63-65.

Sikarwar R. 1994. Biology of the endangered Mahaseer fish Tor tor and methods of its conservation in Narmada river Ph.D. Thesis, Vikram Univ. Ujjain (M.P.) 1-170 pp.

Sikder, S.K., and Das, A. 1980. Investigation on fish Mastacembelus armatus skin: Part 2, isolation and characterization of glycosaminoglycans (Mucopoly saccharides). Indian J. Chem., Sect. B, 19, pp. 423-424.

Simpson A. C. 1951. Fecundity of plaice. Fishery Invest. London: Sem .217(15: 27). 